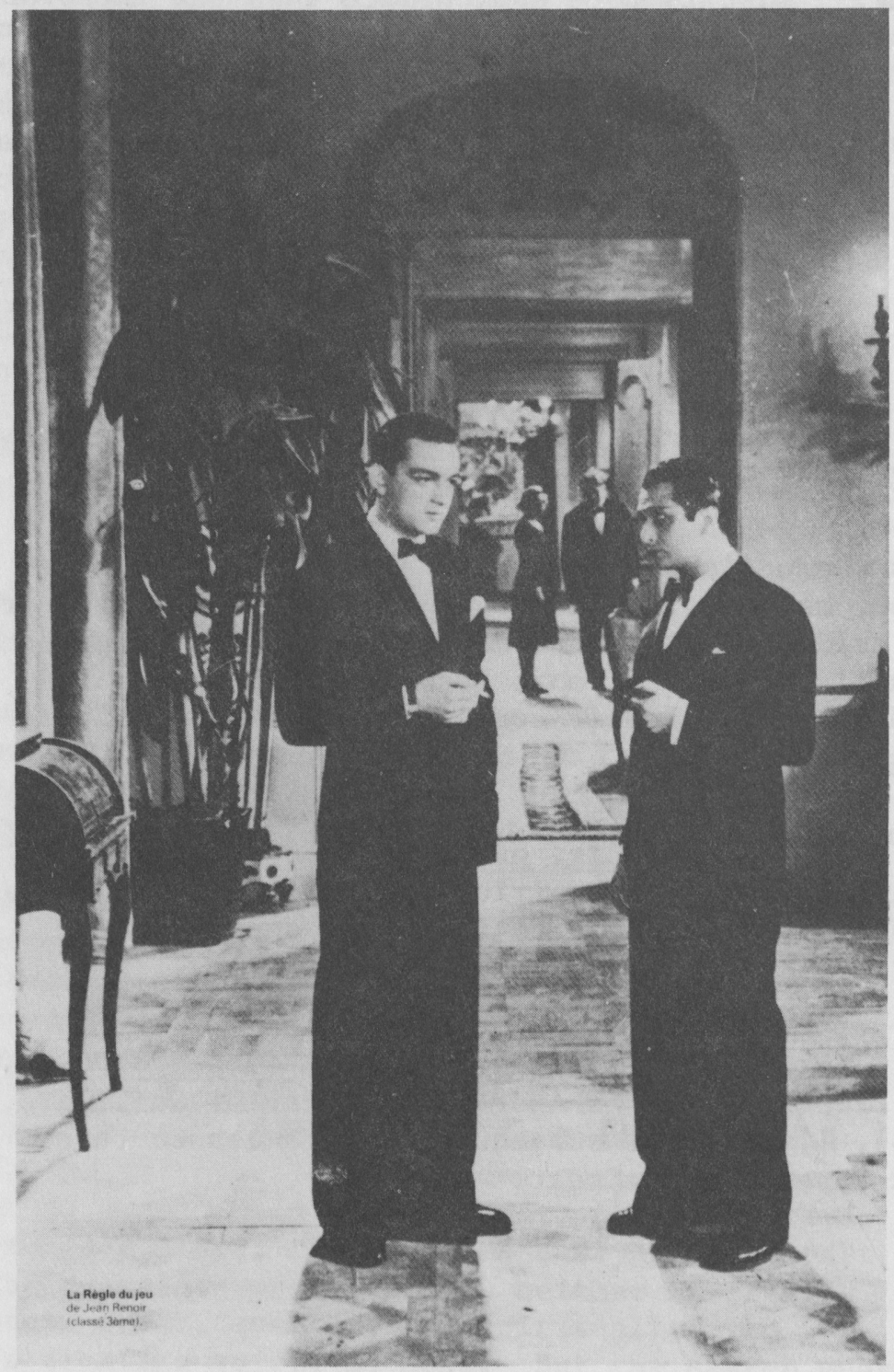

Marcel Dalio (playing the role of Robert de 1a Chesnaye), right, with Roland Toutain (André Jurieu) in Rules of the Game of Jean Renoir. 


\section{Rules of the Game: Characterization \\ of Robert de la Chesnaye}

Because it is an intricate portrait of the upper social class, Jean Renoir's film, The Rules of the Game, has been taken to be a critical comment on this segment of society. Renoir denies this, saying that it was not critical and that his concern was rather that this social class was in the process of disappearing. What his film does portray is a society in which it is necessary to know the rules and to follow them in order to survive. The character of the Marquis, Robert de la Chesnaye, is the central figure in the development of this theme. It is essential to understand the character of Robert in order to understand the society that is portrayed in the film. In this study, one must consider how Renoir develops the character of Robert; one must also examine the continuing changes in this character and the relationships between Robert and the other characters.

Renoir's choice of Marcel Dalio to play the part of Robert reflects Renoir's insight in casting his characters. He was trying to stay away from the cliché of a marquis, and so chose Dalio, who had played only burlesque parts before taking the part of Robert de 1a Chesnaye. Dalio brings with him the essence of the character of Robert. As an actor playing a role, Dalio creates the character from parts of himself as well as assumes characteristics from the script; he trans'forms the written sketch into a realistic and living individual.

One must look at the facts given in studying the character of Robert. The script gives the following information: he is the Marquis de la Chesnaye, has inherited wealth, is of high social class, his mother was Jewish whose maiden name was Rosenthal, he has an Austrian wife, Christine, and a mistress, Genevieve. 
One learns that he collects mechanical and musical toys, and his chef informs us that he is a "man of the world" because he knows the proper was to prepare potato salad and insists that it be done correctly.

In the first part of the film it is difficult to get a tangible idea of what Robert de la Chesnaye is like and to understand what he feels about his life and the people around him. He gives no outward signs of emotion or of what goes on inside his mind. One must therefore examine the indications of his personality given by his conversation, his manner and the reactions of other characters to him. Unlike Jurieu, who tells all the world of his disappointment in the woman he loves, Robert keeps everything inside. He is surprised to learn that his discreet affair with Genevieve is known by Octave, and he is at first shocked to think of inviting Jurieu to La Colinière because of the apparent implication that his wife is having an affair. Robert remains enigmatic throughout the film, only revealing himself from time to time. This outward appearance, maintained at all cost no matter what it hides, is one of the most important aspects of this social class, and this aspect is emphasized throughout the film.

Robert is a man who has all the social skills necessary to sustain his place in society. He is known as a wonderful host and an imaginative man who can put on an entertaining hunt for many guests. He concludes the day of the hunt at La Colinière with an original program of song and dance complete with costumes and ending with its own danse macabre.

As a "man of class," Robert treats everyone with the utmost courtesy; he welcomes and is polite to Jurieu; with Marceau the poacher he exhibits an unusual willingness to talk, even displaying a disinterested curiosity in how Marceau traps rabbits. His offer of a position to Marceau lacks the real concern and interest that would label it an act of kindness, however, and one attributes the act more to a whim of 
Robert executed with his usual nonchalance.

One sees Robert attentive to small matters, such as finding the lost key to one of his mechanical birds, yet indifferent to matters concerning the management of his estate. He tells Schumacher, "I don't want any wire-netting, and I don' $t_{1}$ want any rabbits: the rest

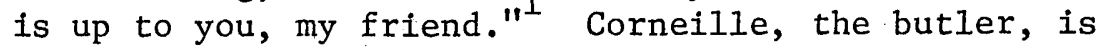
responsible for all the details with which Robert can't be bothered: "Get Corneille to deal with the formalities, the telephone calls and all the rest" (p. 167). Most importantly, he refuses to try and keep Christine and Jurieu apart:

Robert: But, of course, everyone has their own good reasons--and I, I want everyone to give them freely. I am against barriers, you know, I am against walls. Anyway, that's why I'm going to invite André.

Octave: You think it's a good idea?

Robert: A good idea? I trust Christine. If she is to fall in love with Jurieu, I won't be able to prevent her from doing so by separating them. So, the more they see each other, the more things will get cleared up. (p. 53)

This short dialogue clarifies an important belief of Robert: each individual does have his own reasons, and Robert himself believes these reasons to be valid when they are expressed. Each individual has a right to his reasons in qualifying his actions. In accepting all reasons given by others for their actions, Robert in turn simply expects the same courtesy.

After introducing the character of Robert de la Chesnaye, Renoir then allows him to develop. The fact that the character of Robert is not static is important to the development of the film. One sees the evolution of Robert portrayed on the screen; each change is important to the final outcome. The more constant qualities of his personality have been 
studied. Now one must apply this knowledge to the portrait of Robert in the process of change. At the beginning, we see that he has just made a decision meant to change his whole life: he has decided to break off his affair with Genevieve. Robert admits, apparently to his surprise, that, although he does love one woman more than the other, he hates to hurt anyone.

Robert: The Moslems are the only ones who've shown the slightest sense in this notorious question of relationships between women and men.

Marceau: We11!

Robert: Bah! In the end, they're built the same way as us!

Marceau: You said it...

Robert: There's always one woman they like best.

Marceau: Yes . .

Robert: But they don't think that just because of that they have to throw the others out . . and make them suffer. (p. 122)

Nevertheless, Robert does seem a bit hard-hearted when he finally telles Genevieve during the hunt scene that their affair is over. He tells her he is tired of being "Paris without the apple" (p. 103) and he really doesn't want to talk about it anymore. He has ended the affair in his mind and thinks she should accept the decision as easily. He cannot, however, be really cruel to Genevieve, and he consents to one last show of affection that Christine sees through the binoculars.

Robert's relationship with Christine seems at first cool and unemotional. He doesn't express jealousy over her friendship with Jurieu; his concern is more with appearances, as indicated above. This is vividly illustrated in the deep focus shot of Robert 
and Octave moving in behind Christine as she explains to all the guests gathered at La Colinière both her friendship with André Jurieu and her rôle in his successful flight. The worried expression on Robert's face immediately relaxes and changes to a pleasant welcome when he sees that Christine has preserved appearances. The General remarks that "our dear Christine has class and that is something you don 't see much of these days, not much" (p. 85). The General's remark bears witness to the social form observed by Christine.

The characters' emotions are intensified while the program is being performed for the guests, especially during the danse macabre. The actions of the individual characters reflect a change. For a short time all the masks generally hiding the real appearance of the characters even slip just a little, just enough for one to glimpse a truer picture of their emotions. In this series of vignettes, one sees Robert in conversation with various other characters. The discontinuity of the action emphasizes the emotional fragmentation of each character. Each phrase spoken by Robert is set apart and is indicative of the direction the action is taking. Similarly, each scene with Robert is broken up by shots of Schumacher, Lisette, and Marceau chasing each other through the château, or by short shots of the program and the danse macabre still going on for the audience of guests who suspect nothing of the events taking place around them. The camera follows servant and master alike who chase each other through the rooms of the château, switching back to the danse macabre to present a startling sequence of images.

It is at this point in the film that Robert begins to act in a manner uncharacteristic of his actions displayed up to this time. He is no longer the self-contained, calm and unemotional character that we have seen before. He becomes, instead, determined to find Christine, who has disappeared with 
Saint-Aubin, another one of her admirers. Robert, who before this time disdained any semblance of jealousy, now seems completely overtaken by it. After Jurieu's confrontation with Saint-Aubin, Robert confronts Jurieu: "It seems to me . . . that you have achieved your ends. You are in the process of stealing my wife from me" (p. 136). Robert then loses his control completely and even fights physically with Jurieu. Next, his broken phrases show him asking. Jurieu to forgive him: "You must accept my apology" and "Like a real peasant" (p. 148). Robert is once more the usual self-contained, unruffled gentleman, maintaing a perfect exterior. He is now concerned with Jurieu's job as a pilot and with the possibility of his death in such a dangerous occupation. Finally, Robert's ultimate concern is that Christine be taken care of in the manner to which she is accustomed. After such a display of jealousy, his calm and matter of fact approach to the problem seem incongruous, but again it is a matter of maintaining outward appearances, One hears him tell Jurieu that he has not believed in anything in a long time, but he's beginning to believe in friendship. Here he is speaking of friendship with octave. The remark seems to echo ironically. when the scene is juxtaposed with another showing Octave making plans to run away with Christine: she is disappointed in Jurieu who would not go without speaking to her husband.

When it is discovered that Christine has disappeared, one sees that Robert, who really loves her, is probably realizing the extent of his love for the first time, only at the moment he is losing her. He again preseryes appearances in the midst of an emotional crisis. He tells his guests that Christine was a trifle tired and has gone to bed early. In these last scenes of the film Robert is calm and in perfect command of himself in spite of the fact that his wife has just left him. Robert's summation of the accidental death of Jurieu at the end of the film again emphasizes what has remained a most im- 


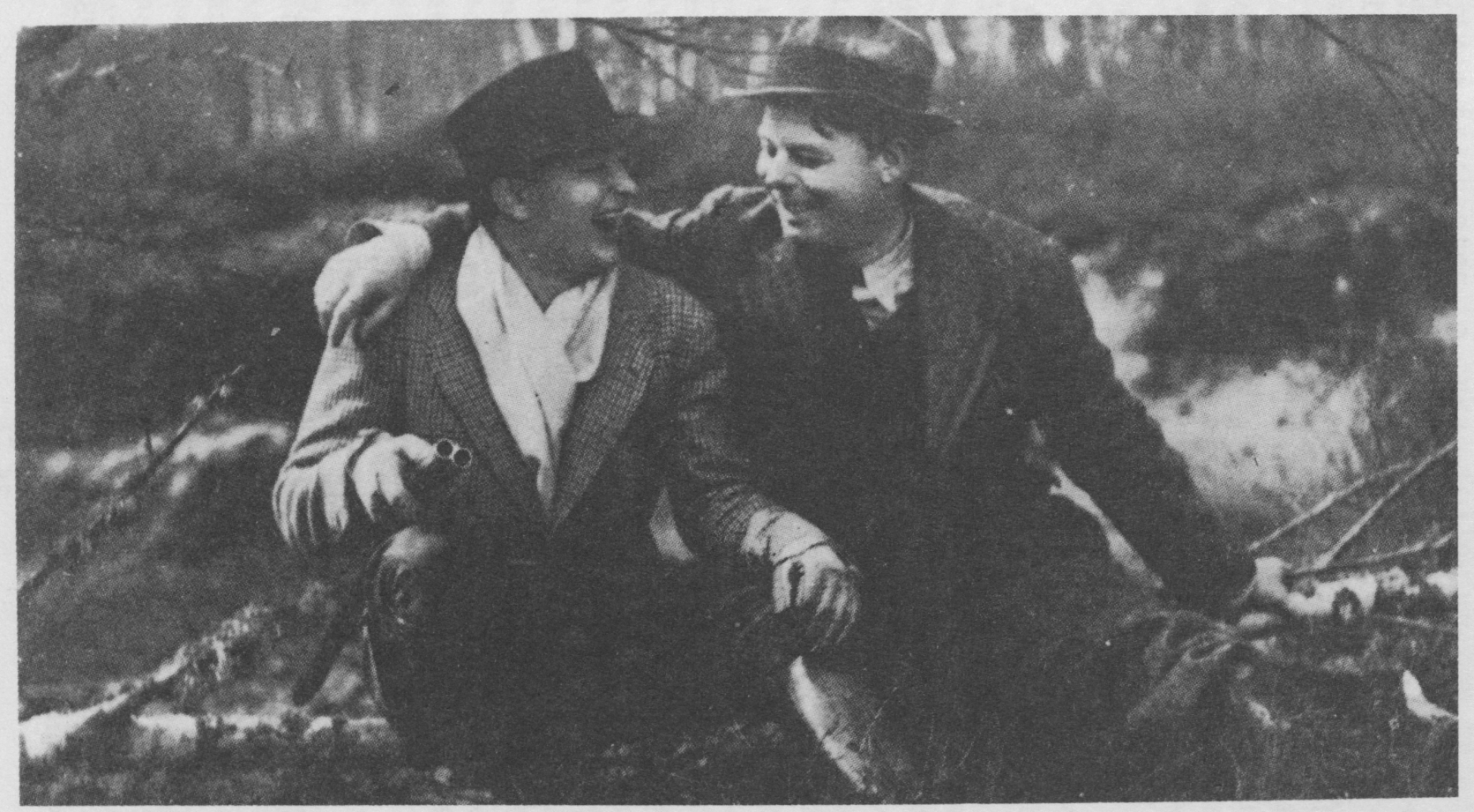

Jean Renoir in his film, Rules of the Game, playing the role of Octave, right, with Roland Toutain, playing the role of André Jurieu. 
portant element throughout the film: that the outward semblance of order and reason is all important. For describing the shooting of Jurieu, Robert is actually reinforcing the idea that one must maintain an appearance of perfect behavior no matter what has gone on behind the façade:

Gentlemen, there has just been a deplorable accident, that's all . . . My keeper Schumacher thought he saw a poacher, and he fired, since that is his duty. . . Chance had it that André Jurieu should be the victim of this error. . . . Gentlemen, tomorrow we shall leave the château weeping for this wonderful friend, this excellent companion who knew so well how to make us forget that he was a famous man. (A pause.) And now, my dear friends, . . it is cold, you are running the risk of catching a chill and I suggest that you go inside. Tomorrow, we will pay our respects to our friend Jurieu . . ( $(p, 168)$

And the General again portrays the habit of hiding reality behind the façade of good manners as a virtue to be admired:

Saint-Aubin: A new definition of the ACCIDENT!

General, sharply: No, no, no, no, no! La Chesnaye does not lack class, and that is a rare thing, these days, my dear SalntAubin, believe me, that is a rare thing! (p. 168)

This insistence on the high quality of Robert's actions and words again evokes the image of this society in which rules are so important. Even though each individual may have his reasons for whatever 
actions he chooses to take, following the rules will guarantee his survival.

The character of Robert is central to the theme of the film. It incorporates all the qualities that Renoir sees in this class of society as it is disappearing. Robert de $1 \mathrm{a}$ Chesnay is without a doubt an individual, not a stereotype of a marquis. Nonetheless, he symbolizes all the men of his social class, all the nobility and all the wealthy people who were beginning to lose their place in an ever changing society.

In allowing the character of Robert to have a life of his own, Renoir also allows him to be inconsistent. That is why Robert can evolve during the events of the film and why he can display opposite qualities. He can be competent and incompetent, intense yet aloof, proud at the same time as being unsure of himself. The scene where he displays his new mechanical organ to the guests at La Colinière best illustrates the complexity of his character. There is no dialogue; one sees only Robert standing beside his wondrous toy, presenting it to his friends with a mixture of pride and timidity. He seems to have stage fright. Renoir doesn't explain Robert to us. He allows Robert to explain himself or not explain himself, as the case may be. Robert tells us about himself by his actions, his speech, and his facial expressions caught by the camera. His character is thus rendered completely realistic, as enigmatic and contradictory as a living individual would be.

Robert is moreover the catalyst among the characters of the film. In not making decisions for people, such as his refusal to keep Jurieu away from Christine, he becomes in large part the cause of the events that take place. He hires Marceau for no apparent reason, setting off the jealous rage of Schumacher. This rage in turn serves as the instrument by which Jurieu is killed. This strange twist 
of events is ironic in that Jurieu, in the midst of planning to run away with another man's wife, is killed by a jealous man. Though it is by the wrong man, the shooting of Jurieu seems somehow consistent with the sequence of events. Robert's earlier decision to terminate the affair with Genevieve and the subsequent scene between the two seen by Christine causes Christine to make a decision of her own: to leave Robert, who does not appear to love her as she thought. This action taken by Christine illustrates how, even indirectly, all events stem from Robert: by his action or lack of action another action is set in motion. Robert's relationships with the people around him lead each one of them in turn to act and react in certain unpredictable ways. As his authority over others is more a knowledge of who he is than a manifestation of authoritative action, Robert's influence is often an invisible force.

Robert exemplifies the aristocrat in his aloof, untouchable behavior, not quite condescending, yet on a level entirely different from the level of those surrounding him. His relationships are representative of his social level also. They are factitious. The real emotions, which still exist after so much repression, are always masked. La Chesnaye seems to be quite lacking in the usual emotions. But if one wonders whether he has not almost lost them through disuse, the emotions are there and they are awakened.

In Robert de la Chesnaye we have the portrayal of the level of society Renoir chose to study. Robert exhibits representative behavior both in his individual actions and in his relationships with his wife, mistress and friends around him. Robert is not meant to be a criticism of this particular society. He merely represents it, with all the good and bad qualities combined. He can be appreciated for his charm and wit as well as criticized for his shortcomings. Renoir holds to the belief expressed by Robert in the film that everyone has his reasons. 
Renoir accepts them all and wants to give others the, freedom to express them. In the same manner, Renoir does not justify the qualities of this society; neither does he criticize them.

\section{ALETA RAY}

UNIVERSITY OF KANSAS

\section{NOTE}

1 Jean Renoir, The Rules of the Game, film script trans. John McGrath and Maureen Teitelbaum (London: Lorrimer Publishing, 1970), p. 57. Ali references to the script are from this edition. 


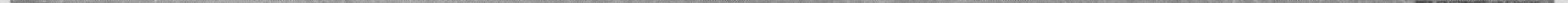

